\title{
Post-operative Recovery Assessment of Urinary Tract Dysfunction Following Radical Hysterectomy for Cervical Cancer Patients
}

\section{Kajian Pemulihan Fungsi Berkemih pada Pasien Kanker Serviks Pascahisterektomi Radikal}

\author{
Laila Nuranna, Sang A F Adi Kusuma \\ Department of Obstetrics and Gynecology \\ Faculty of Medicine Universitas Indonesia/ \\ Dr. Cipto Mangunkusumo Hospital \\ Jakarta
}

\begin{abstract}
Objective: To assess the length of recovery phase in urinary tract dysfunction following radical hysterectomy for cervical cancer patients in Dr. Cipto Mangunkusumo Hospital.

Methods: This survey study was conducted at Dr. Cipto Mangunkusumo Hospital from September 2016 to May 2017. Subjects were cervical cancer patients from stage IA2 to IIA2 who underwent radical hysterectomy. A suprapubic catheter (SPC) was inserted to observe the urine production after the procedure. Patients were then directed for bladder training protocol involving clamping and opening SPC. Sensation of bladder fullness followed by spontaneous micturition was recorded. Measurement of post-voiding residual (PVR) urine volume after spontaneous micturition until less than $100 \mathrm{ml}$ was considered as the resolution of urinary tract dysfunction. The average days of every achieved phase were then calculated.
\end{abstract}

Results: Twenty-nine subjects underwent radical hysterectomy during the observation period. However, only 21 subjects continued the bladder training protocol and recorded for the recovery phases. The average time needed to obtain sensation of bladder fullness and spontaneous micturition was $7.57 \pm$ 4.78 days (median 5 days, minimum 3 days, maximum 22 days) and $8 \pm 5.21$ days (median 6 days, minimum 3 days, maximum 23 days). The objective PVR urine became less than $100 \mathrm{ml}$ was obtained after $21.42 \pm 18$ days (median 18 days, minimum 7 days, maximum 74 days).

Conclusion: Following radical hysterectomy, recording the recovery phase of urinary tract dysfunction is essential to ensure complete resolution. Complete resolution of the urinary dysfunction is achieved after $21.42 \pm 18$ days in average (median 18 days, minimum 7 days, maximum 74 days).

[Indones J Obstet Gynecol 2018; 6-4: 257-260]

Keywords: cervical cancer, post-voiding residual volume, radical hysterectomy, urinary tract dysfunction

\begin{abstract}
Abstrak
Tujuan: Menilai masa pemulihan disfungsi saluran kemih setelah histerektomi radikal pada pasien kanker serviks di RSUPN Dr. Cipto Mangunkusumo.

Metode: Studi survei dilakukan di RSUPN Dr. Cipto Mangunkusumo dari September 2016 hingga Mei 2017. Subjek penelitian terdiri atas pasien kanker serviks stadium IA2 hingga IIA2 yang menjalani histerektomi radikal. Kateter suprapubik (SPC) digunakan sebagai alat untuk memantau produksi urin pascaoperasi. Pasien diinstruksikan untuk mengikuti protocol bladder training yaitu melalui prosedur menutup, dan membuka kateter. Rasa sensasi ingin berkemih dan berkemih spontan. Pengukuran residu volume urin pascaberkemih di bawah $100 \mathrm{ml}$ dianggap merupakan indikator pemulihan disfungsi saluran kemih. Rata-rata hari dari tiap fase kemudian dihitung.
\end{abstract}

Hasil: Dua puluh sembilan subjek didapatkan selama penelitian. Namun, hanya 21 subjekyang dapat mengikuti protocol bladder training dan dicatat perkembangan pemulihannya. Rata-rata hari yang diperlukan untuk merasakan sensasi berkemih dan berkemih spontan adalah 7,57 \pm 4.78 hari (median 5 hari, minimum 3 hari, dan maksimum 22 hari) dan $8 \pm 5.21$ hari. (median 6 hari, minimum 3 hari dan maksimum 23 hari) Rata-rata hari untuk mencapai residu urin di bawah $100 \mathrm{ml}$ adalah $21.42 \pm 18$ (median 18 hari, minimum 7 hari, dan maksimum 74 hari).

Kesimpulan: Setelah prosedur histerektomi radikal, pencatatan masa pemulihan penting untuk dipantau untuk memastikan pemulihan lengkap. Rata-rata hari yang diperlukan untuk pemulihan adalah 21,42 18 hari (median 18 hari, minimum 7 hari, dan maksimum 74 hari).

[Maj Obstet Ginekol Indones 2018; 6-4: 257-260]

Kata kunci: disfungsi saluran kemih, histerektomi radikal, kanker serviks, volume residu pascaberkemih

\section{INTRODUCTION}

Cervical cancer is the third most common female cancer occurs in Indonesia following breast and colorectal cancer. ${ }^{1}$ To date, the treatment of cervical cancer is still limited to specific surgery (radical hysterectomy), radiotherapy, chemotherapy and chemoradiation. The 5-year survival rate for both radiotherapy and radical hysterectomy reach up to $85 \%$, but the after-effect of each treatment is different. $^{2}$

Radical hysterectomy procedure for cervical cancer affects the urinary tract in short and long- 
term. Long-term effects occur approximately in 8$80 \%$ of the population according to the institution. ${ }^{3}$ The most common one is voiding dysfunction. ${ }^{4}$ Study conducted in Thailand showed $25.1 \%$ of the patients in early stage who underwent radical hysterectomy had symptomatic bladder dysfunctions such as incomplete bladder emptying, urgency, nocturia, terminal dribbling, frequency and micturition pain. ${ }^{5}$

Short-term effects occur in lower urinary tract such as loss of bladder sensation, inability to void and vesicoureteral reflex. In three months evaluation after the procedure, some of the patients showed several symptomatic bladder dysfunctions such as frequency, urgency, while the other side showed diminished bladder sensation, voided by abdominal straining, urine retention, mild stress incontinence and difficulty in initiating micturition with suprapubic catheter inserted for 35-39 days. ${ }^{6}$

In two weeks of observation, all the patient who underwent radical hysterectomy showed voiding sensation dysfunction and $68 \%$ had residual urine in their bladder. ${ }^{7}$ There is still no adequate data for the incidence of bladder dysfunction globally. These urine dysfunctions lasted for one to six months in $13 \%$ of the patients, while the other 3\% lasted for more than six months. ${ }^{8}$ Shingo Fuji et al. showed $92 \%$ of the patients would have the sensation of bladder fullness, and only $71 \%$ obtained the satisfaction of micturition 14-days after surgery. These were objectively evaluated by measuring post void urine residual volume under $50 \mathrm{ml}$ only in $46 \%$ of patients 14 -days after surgery. ${ }^{9}$

Obstetric and Gynecologic Department Oncologic Division in Dr. Cipto Mangunkusumo Hospital has been doing radical hysterectomy procedures for cervical cancer patients for years. However, until today, the study for evaluating the after effects from the procedure, the recovery phase and the therapies is still limited.

\section{OBJECTIVES}

This study is aimed to observe the recovery phase of the urinary tract dysfunctions following radical hysterectomy in cervical cancer patients in Dr. Cipto Mangunkusumo Hospital. We also want to observe the period needed to achieve full bladder sensation, spontaneous micturition and to have post-void residual volume below $100 \mathrm{ml}$ in cervical cancer following radical hysterectomy procedures in Dr. Cipto Mangunkusumo Hospital.

\section{METHODS}

This study is a cross-sectional study conducted in 7 months (September 2016 - May 2017) in Dr. Cipto Mangunkusumo Hospital, Jakarta. The subjects were cervical cancer patients stage IA2, IB1, IB2, IIA1 and IIA2 who underwent radical hysterectomy, did not have any urinary tract dysfunctions, not under any urinary tract treatments such as alpha-blockers, never had any surgeries involving urinary tracts, not in the radiotherapy nor chemotherapy before radical hysterectomy, did not have vesicovaginal and retrovaginal fistules after surgery, did not use indwelling Foley catheter in the bladder training.

Subjects were collected from elective radical hysterectomy surgery patients until fulfilled the minimum sample of 21 subjects (as calculated previously), then they were followed for the urinary tract functions after the procedure. The subjects who fulfilled the criteria were asked for the availability for observation (informed consent). The data were collected from the history taking, physical examinations and the medical record. Suprapubic catheter was inserted to monitor the urine production after the surgery. The patients were instructed to clamp and open the catheter according to the bladder training protocol. The training started on the third to eighth-day post operation or when the patients start to feel the full bladder sensation. The bladder training was guided by the nurses assisted and accompanied by the family members. The catheter was clamped at 06.00 am will be opened periodically every 4 hours in exact time (10.00,14.00, 18.00 and 22.00). The catheter will remain open from 22.00 to 06.00 in the night. Every spontaneous micturition, the urine would be collected and measured, then the patient or the family member recorded the volume in the bladder diary given by the nurse. Following the spontaneous micturition, the suprapubic catheter would be kept open for 5 minutes, and the residual urine would flow through the suprapubic catheter, and the residual urine volume would be then recorded also in the bladder diary. If there were no sensation to micturate until 4 hours, the clamp would be opened on the exact time given $(10.00$, $14.00,18.00$ and 22.00) for 5 minutes, and then the volume was recorded. 
The time needed to achieve full bladder sensation and spontaneous micturition were then observed. Post-voiding residual urine volume below $100 \mathrm{ml}$ considered to be the objective indicator for recovery of urinary tract dysfunctions. Data were then analyzed by SPSS for Mac vers. 20.0. Data with normal distribution were reported as mean and standard deviation, while the abnormal data distribution would be reported as median with minimum and maximum value.

\section{RESULT}

Twenty-seven subjects enrolled in this study. Six subjects were excluded from this study due to ureter malinjury and vesicovaginal fistula, detached suprapubic catheter or false-route in early placement, and consideration of surgical operator to use foleycatheter for bladder function monitoring.

\section{Subject Characteristic}

Eleven subjects were under laparotomy radical hysterectomy, while another 10 subjects were under laparoscopy. Most subjects (6 subjects, 23.8\%) are in the range 40-44 years old and suffer from cervical cancer stage IB1 (7 subjects, 30.4\%). No subjects are in stage IA2. Distribution of age is normal according to Shapiro-Wilk Test. Distribution of days needed to achieve full bladder sensation, spontaneous micturition, and residual urine below $100 \mathrm{ml}$ are not normal (Table 1).

Table 1. Subject Characteristic According to Age and Cervical Cancer Stage

\begin{tabular}{cl}
\hline \hline Age (year) & (\%) \\
\hline $30-34$ & $1(4.8)$ \\
$35-39$ & $4(19)$ \\
$40-44$ & $5(23.8)$ \\
$45-49$ & $3(14.3)$ \\
$50-54$ & $2(9.5)$ \\
$55-59$ & $3(14.3)$ \\
$>60$ & $3(14.3)$ \\
Stage & \\
IA2 & $0(0)$ \\
IB1 & $7(33.3)$ \\
IB2 & $4(19)$ \\
IIA1 & $5(23.8)$ \\
IIA2 & $5(23.8)$ \\
\hline \hline
\end{tabular}

\section{Overview of Postoperative Bladder Dysfunction Recovery}

During bladder function monitoring, bladder training was started on postoperative day 3 until postoperative day (POD) 8 depended on the surgeon's decision. In study of Fujii et al., Foley catheters were withdrawn on POD 9. No single agreement or pilot study is explaining the most proper time to withdraw the Foley catheter and start the bladder training. ${ }^{9}$

In this study, POD 14 and 21 were used to evaluate the bladder function in accordance to Fujii et al. study. ${ }^{9}$ The earliest micturition sensation was achieved on POD 3 during postoperative monitoring of bladder function recovery. The longest period needed to achieve sensation was POD 22. Earliest spontaneous micturition was achieved on POD 3, and the longest was on POD 23. The earliest days needed to achieve residual urine below $100 \mathrm{ml}$ was 7 days post operation while the longest was on POD 36.

On POD 21, only 13 subjects (61.9\%) were already achieved residual urine below $100 \mathrm{ml}$. The average days needed to achieved residual urine below $100 \mathrm{ml}$ is $21.43 \pm 8$ days (median 7 days). See Table 2.

Table 2. Bladder Dysfunction Recovery Overview

\begin{tabular}{lccc}
\hline \hline & $\begin{array}{c}\text { Full bladder } \\
\text { sensation }\end{array}$ & $\begin{array}{c}\text { Spontaneous } \\
\text { micturition }\end{array}$ & $\begin{array}{c}\text { Residual urine } \\
<\mathbf{1 0 0 m l}\end{array}$ \\
\hline Post Operative Day 14 & $90.4 \%(19 / 21)$ & $85.7 \%(18 / 21)$ & $38.1 \%(8 / 21)$ \\
Post Operative Day 21 & $95.2 \%(20 / 21)$ & $95.2 \%(20 / 21)$ & $61.9 \%(13 / 21)$ \\
Average (days) & $7.57 \pm 4.78$ & $8 \pm 5.21$ & $21.42 \pm 18$ \\
Median (days) & 5 & 6 & 18 \\
Minimum (days) & 3 & 3 & 7 \\
Maximum (days) & 22 & 23 & 74 \\
\hline \hline
\end{tabular}

On POD 14, 90.4\% subjects (19 subjects) have already felt full bladder sensation, and $85.7 \%$ subjects (18 subjects) have already achieved spontaneous micturition. This data are not much different from Fujii et al. study which 91.7\% subjects have felt full bladder sensation and $45.8 \%$ subjects objectively achieved residual urine below $100 \mathrm{ml}$. Fujii et al. did not evaluate spontaneous micturition in subjects.

On POD 21, 95.2\% subjects (20 subjects) felt full bladder sensation and achieved spontaneous micturition. This data is not much different from Fuji et al. study which all of the subjects (24 subjects) 
are no longer suffered from bladder dysfunction on POD 21.9

The outcome difference between this study and Fujii et al. study mainly due to radical hysterectomy technique performed. In Fujii et al., nerve-sparing radical hysterectomy were applied to all subjects, while in this study, we did not differentiate between laparotomy and laparoscopy technique nor nerve sparing and non-nerve sparing technique. This could be one of weakness in this study where variables influencing were not analyzed.

Many studies have reported urinary tract dysfunction after radical hysterectomy. Voiding dysfunction is most problems reported. Buchsbaum et al. reported urinary retention in $10 \%$ $60 \%$ post radical hysterectomy patients. It used to be treated with intermittent catheterization. ${ }^{10}$ This voiding dysfunction is persistent in $5 \%$ and becomes long-term bladder dysfunction. There is no clear definition between short term and long term bladder dysfunction. 6,11

Even though there is no clear definition of bladder dysfunction after radical hysterectomy, this study is aimed to know the recovery period of short-term bladder dysfunction. The main purpose is giving clearer information to cervical cancer patients who undergo radical hysterectomy about the procedure and also the side effects. In daily practice, radical hysterectomy will affect the urinary function and increasing probability of Foley catheter placement in the long run. Decreasing total bladder capacity and worsening residual urine volume. ${ }^{11}$ Therefore, it is crucial to be acquainted with the average recovery period of bladder dysfunction after radical hysterectomy. On final point, the data can be used to form guidelines in managing bladder dysfunction after radical hysterectomy especially when further intervention is needed.

It is important to consider the education level of each patient, especially in recording bladder diary. The accuracy of residual urine measurement can be doubted if the patient never empties the urine bag after every micturition process. It is best anticipated to ask one of the family members to assist the monitoring process.

\section{CONCLUSION}

In this study, the average days to achieve full bladder sensation in Dr. Cipto Mangunkusumo Hospital was 7.57 (median 5 days). The spontaneous micturition was achieved after 8 days on average (median 6 days). Residual urine under $100 \mathrm{ml}$ was achieved after 21.42 days on average (median 18 days). This overview of bladder dysfunction recovery is essential in giving patient education. Each patient should know that radical hysterectomy produces bladder dysfunction and the recovery will take an exact period of time. Continuous and repeated education is important for patient, family, medic and paramedic staffs especially in recording the bladder diary.

\section{REFERENCES}

1. Pusat Data dan Informasi Kementerian Kesehatan RI. Situasi Penyakit Kanker. 2015: 9.

2. Berek JS. Cervical and Vaginal Cancer. In: Berek \& Novak's Gynecology. Lippincott Williams \& Wilkins; 2007: 1417-31.

3. Zullo MA, Manci N, Angioli R, Muzii L, Panici PB. Vesical dysfunctions after radical hysterectomy for cervical cancer: a critical review. Crit Rev Oncol Hematol. 2003; 48(3): 28793.

4. Mundy AR. An anatomical explanation for bladder dysfunction following rectal and uterine surgery. Bri J Urol. 1982; 54(5): 501-4.

5. Charoenkwan K, Pranpanas S. Prevalence and characteristics of late postoperative voiding dysfunction in earlystage cervical cancer patients treated with radical hysterectomy. Asian Pac J Cancer Prev. 2007; 8(3): 387-9.

6. Farquharson DI, Shingleton HM, Orr JW, Hatch KD, Hester S, Soong SJ. The short-term effect of radical hysterectomy on urethral and bladder function. Bri J Obstet Gynaecol. 1987; 94(4): 351-7.

7. Ralph G, K Tamussino, et al. Urodynamics following radical abdominal hysterectomy for cervical cancer. Arch Gynecol Obstet. 1988; 243(4): 215-20.

8. Green TH, Meigs JV, Ulfelder H, Curtin RR. Urologic complications of radical Wertheim hysterectomy: incidence, etiology, management, and prevention. Obstet Gynecol. 1962; 20: 293-312.

9. Fujii S, Takakura K, Matsumura N, Higuchi T, Yura S, Mandai $\mathrm{M}$, et al. Anatomic identification and functional outcomes of the nerve sparing Okabayashi radical hysterectomy. Gynecol Oncol. 2007; 107(1): 4-13.

10. Tunuguntla HSGR, Rodriguez LV, Gousse AE. Voiding Dysfunction After Pelvic Surgery. In: Female Urology. Elsevier Saunders; 2008: 77-80.

11. Thakar R, Sultan AH. Hysterectomy and pelvic organ dysfunction. Best Pract Res Clin Obstet Gynecol. 2005; 19(3): 403-18. 